\title{
CUSTOM-MADE PATCHWORK LANDSCAPE: ENTREPRENEURIAL AND PRIVATE REGIONALISM
}

\author{
Ilze Mikselsone \\ Riga Technical University, Faculty of Architecture, Riga, Latvia \\ E-mail Ilze@taktila.lv
}

\begin{abstract}
Regional identity as a subject of invented tradition is continuously updated in whole Europe; this process is especially regular in cultures of small populations, such as Latvia. It is a multilayered term, which involves a continuously changing main value-focus and numerous disciplines, including architecture. One of the ways to look at it realistically is to analyze the visually represented main hegemonic values and processes in society. Appropriate platform for this is provided by agglomeration expansion - fusion spots of the urban and the rural, thus creating a characteristic local landscape. The aim of this article is to clarify core impacts on the regional identity formation of the landscape of Riga region as observed today. Methodology is based on the case study of Mārupe County, using RES (residential) landscape inventory, urban-morphology, photo-analytical and rhetoric problem-definition methodology. Major findings lead to a conclusion of unbalanced role between the state intervention and free trade system, based on the neoliberal ideology intensified in the transition - economy zone. Thus regional spatial identity has mostly failed following any professional standards, but has rather developed as clusters with residential function, mostly under the strong impact of the market economy and entrepreneurship.
\end{abstract}

Keywords: regional spatial identity, suburban landscape, neoliberals, transition economy, patchwork landscape.

\section{Introduction}

Concepts of region and regionalism today are being given an increasing attention in the global, national and urban politics $^{1}$ and policy-making ${ }^{2}$, as well as in development of the social, economic and political theory (Soja 2009). Regional architectural identity is not an exception and its scene has fore-grounded and back-grounded dimensions. Possible descriptions of the foreground characteristics of Riga, the capital of Latvia, could include terrific moments for every taste - a skyline of church towers and Art Nouveau buildings in the historic centre of the city, examples of local modernism in the downtown part or rural ethnographic aesthetics compressed in the Open-Air Museum. The country-specific regional architecture has been analyzed in this paper not through the lens of the aforementioned "selection", but rather through a mass analysis of more extensive subject body - the custom-made patchwork (MacLeod, Ward 2009) landscape. It consists of private residential clusters, formed on the city outskirts

\footnotetext{
1 The practice and theory of influencing other people on a civic or individual level, refers to achieving and exercising positions of governance - organized control over a human community, particularly a state.

2 A statement of intent is implemented as a procedure or protocol.
}

during the last 23 years. Driving to any outskirts of Riga, it is impossible to escape these panoramic views accumulated in the agricultural and forest territories. It becomes a significant topic from the point of regional landscape formation and assessment.

The landscape, according to the European landscape Convention (ELC... 2000), is recognized as an essential component of the human environment, and Latvia has officially accepted this recognition (LPG... 2007). The same document also states that it embodies regionalism, both in objects and organization of space. The architectural theory, defining the credentials of regionalism, sets a single building (Fig. 1) as a form of cultural affirmation in climate embedded traditions, vernacular imitations or even resistance to unfamiliar initiatives (Canizaro 2007). Whereas the research of Montgomery and Maki (1959 (cited from Van Eyck 1962)) on the 'new definition of regionalism', based on the spatial approach, concluded with the statement, that 'it does not arise from characteristic indigenous elements or products, but rather from the manner in which such generalized elements (objects - auth.) are evaluated, organized and expressed' (Van Eyck 1962). This causes one to assume that the realistic regionalism 
shouldn't be hunted in a marginal selection of architectural masterpieces by professionals, but rather in custom-made environments, where the notions of true regional landscape are based on more conventional standards. In his historic review on the evolution of the regional development theories Edward Soja distinguishes 'the emergence after 1980 of a highly competitive entrepreneurial regionalism based on neoliberal ideas' (Soja 2009). Conceivably it refers to both aforementioned approaches (Fig. 1). Trends in private house sizing, aesthetics, typologies and arrangements reflect the general image of the society. Trends of the patchwork layout reflect the dominating process taking place within it.

The United Nations define the urban agglomeration as 'a contiguous territory inhabited at urban levels of residential density, without regard to administrative boundaries' (Beauregard 2010). Suburbia varies widely both between countries and within them. In some countries suburbanization represents the forcing out of the powerless from the city; in others it is a retreat from the city that allows the privileged to perpetuate their advantage (Mace 2009). Problem aspect is defined by the widely acknowledged acceleration in suburbanization processes and similar prognosis about it, - if given the choice, most people would prefer individual living as opposed to the collective one (Nira... 2004) and preferably close to local economic centres. Several studies, undertaken mostly by human, social and political geographers, so far have been investigating the suburbs of Riga with the aesthetic (Zigmunde 2010; Nikodemus et al. 2005), neo-liberal (Darbina, Luse 2006) and border (Pužulis 2012) focus. They outline 'a critical theoretical and empirical engagement with the interpretation of these residential developments as iconic expressions of urban neoliberalisation' (McGuirk, Dowling 2009). In addition to the academic interest in these territories, criticism has been expressed by professionals in the field - architects, planners, environmental specialists. Besides the critical views about the quality of 'dream villages' embodying the market image of the ideal family life, attempts of planners to specify problems (Pužulis, Šķiņ̧̧is 2009) and governmental policies to implement good ideas relevant to applicable regulations (including clearly specified requirements and principles of environmental quality) (MCDP... 2013; RSDS 2030... 2013) for one or another reason fail to develop in a harmonious way. This leads to certain threats and an increasing risk that the chaotic spatial development within the region of Riga is becoming a norm and thus creating a vicious circle - spatial quality influences the residents while the residents influence the spatial quality.
Individual diversity of Private architecture

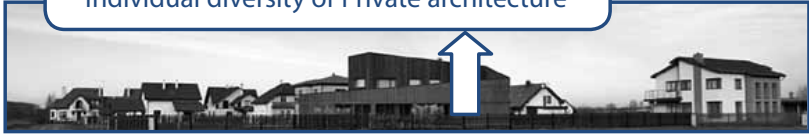

Collective identity of Territory

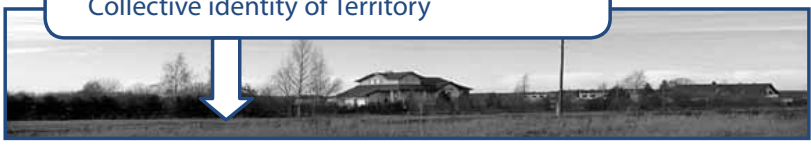

Fig. 1. Scheme of formation of the visual representation of suburban landscape (author's definition, 10.2013)

The subject of suburbs in regard to their patchwork image addresses a wide range of diversity and disparity. In the discourse of theoretical values and their practical implementation Henri Lefebvre writes: "everything (the "whole") weighs down on the lower or 'micro' level, on the local and the localizable - in short, on the sphere of daily life. Everything also depends on this level, exploitation and domination, protection and - inseparably - repression" (Lefebvre 1991). The 'micro level' of daily life also seriously impacts the everyday life in the community of Mārupe. If 'some reasons' rhetorically lead to the idea of notable influence of uncontrolled economic growth in the transitional economic zone, then 'disharmonic ways' refer to the clutter in the scenery and lack of attractive suburban living environment standard. The human geographer Alan Mace writes, 'suburbia represents the physical attempt to mix the urban and rural and is closely associated with the traditional nuclear family, the aspiration for upward social mobility, mass consumption, and commuting. Because of these associations, suburbia has been attacked for being conventional and dull' (Mace 2009).

In order to clarify the core impacts on regional identity formation of the landscape of Riga region as observed today, the paper sets the following tasks: 1) to select and verify the case study; 2) to define and analyse patchwork image within the context of landscape assessment criteria; 3 ) to analyse core impacts between the state intervention in the form of planning policies and the entrepreneurial urban neoliberal's (Brenner, Theodore 2002) activities in the local performance.

\section{Methodology}

Analysis is made on the basis of a case study, selected on the grounds of the following three criteria: 1) the suburb is typical in local conditions; 2) the landscape quality objective is presumed as inactivated; 3 ) notable growth is still expected. Landscape evaluation is always subjective, but it can be described through historical, archaeological, aesthetic, symbolic, ethnological, economic and social values (RCL... 2009). After specifying the built-up environment 
of private housing as the key element of this research, two cornerstones are used here to analyse the landscape formation - governmental policies and national economic policy (Fig. 2).

Based on these two major impacts, presumed to be the most characteristic and misbalanced objectives in terms of 'two rail' standard, the 'patchwork methodology' in the landscape formation is analysed within the following five dimensions (RCL... 2009) (Fig. 3):

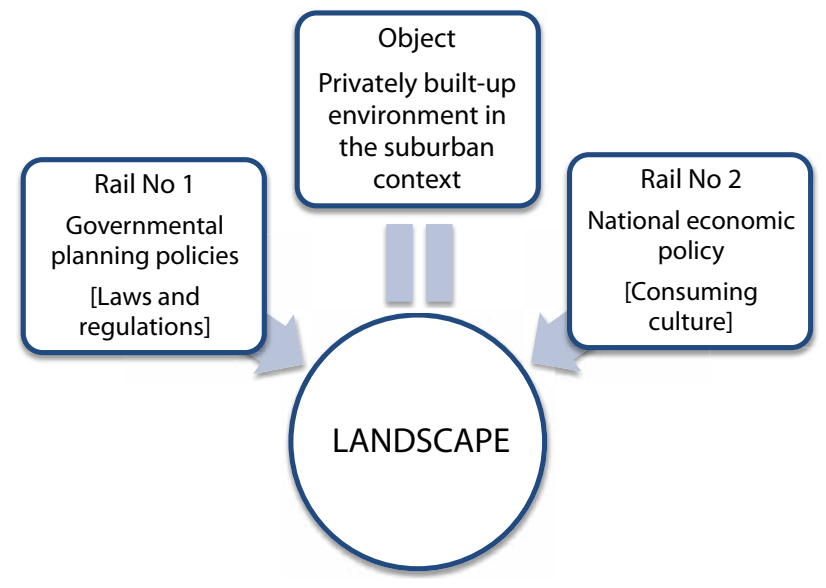

Fig. 2. Methodology: impacts on landscape formation (author's definition, 10.2013)

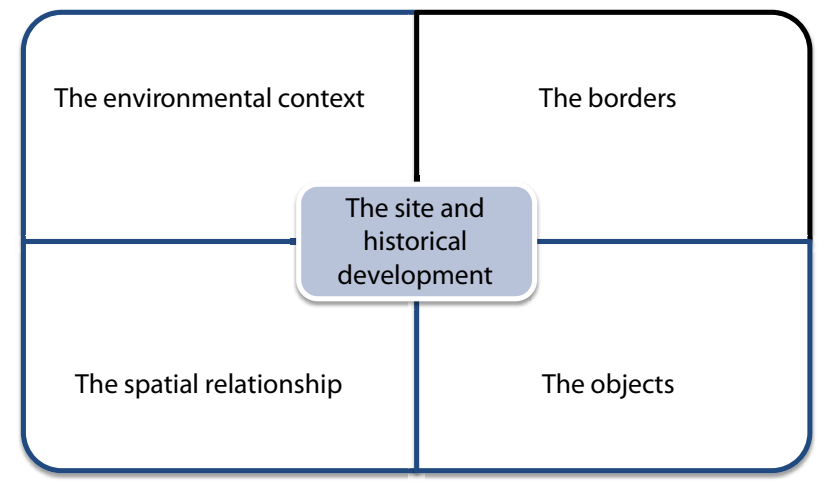

Fig. 3. Methodology: five dimensions in the process of landscape formation (author's definition (according to RCL... 2009), 11.2013)

The $1^{\text {st }}$ : site and historical development of the suburban place (Use of the land and the use of history, cultural traditions and development periods that have affected the landscape and its features (RCL... 2009)). This includes analysis of the basic policies of planning and landscape regulations and outlines of the 23 year long history of economic policy in Latvia;

The $2^{\text {nd }}$ : environmental context (Geography and topography, landscape terrain characteristics (RCL... 2009)). This includes analysis of the landscape context description and gentrification in brown fields;
The $3^{\text {rd}}$ : borders (View, perspective, forming of the surrounding area of the landscape, complex landscape elements, objects and values of public - private relationships (RCL... 2009)). This includes analysis of the patchwork image as territorial forming process in the timeline;

The $4^{\text {th }}$ : spatial relationship (Elements of spatial association, organization, proportions between the buildings, roads, trails, etc. (RCL... 2009)). This includes analysis of the patchwork spatial organization as public-private relationship;

The $5^{\text {th }}$ : objects (Natural and naturalized vegetation, buildings, fences, roads, built or natural water reservoirs, etc. (RCL... 2009)). This includes analysis of the patchwork image as the diversity and disparity of privately owned buildings.

\section{Description of the case study}

Satellite communities around Riga, the capital and the economic centre of Latvia, are often officially subject to different municipality governance, but due to shared mobility and social infrastructure they are included in the recent planning and development strategy plans of Riga (RSDS 2030... 2013) as a whole. This is the case in Mārupe (Fig. 4) - the south-western suburb of Riga as well.

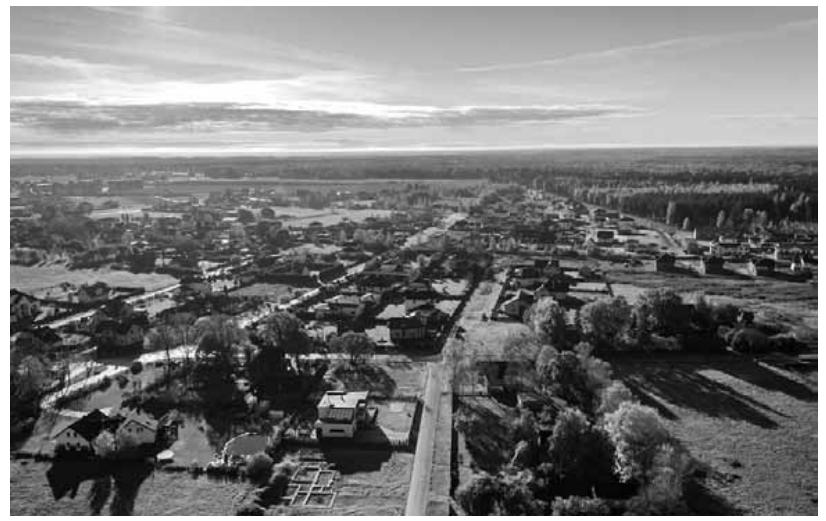

Fig. 4. Panorama view of the case study (www.marupe.lv, 12.2013)

Mārupe is one of the most typical and closest suburbs of Riga. It includes 4 villages with population of 16,157 (2012) in the territorial area of $103.9 \mathrm{~km}^{2}$. During the last decade the population has grown more than 8 times and since 2008 the population growth comprises $28 \%$, which is the third highest density in Riga suburban territories 155.4 residents per $\mathrm{km}^{2}$ and the highest birth rate (2010). The ethnical composition of the population is the following: 69\% Latvian, 19\% Russian and 4\% minorities (2012), 88\% of whom are the citizens of Latvia (2012) and 65\% are of employable age (15-62). More and more people choose 
Mārupe County as their residence because of 'its attractiveness and advantageous geographical position', and it is 'especially popular for family with kids' (MCSDS... 2013). According to the expert provisions of the municipal institutions the estimated maximum population region, that can be provided and maintained with adequate infrastructure and level of comfort, constitutes 30,000 inhabitants. That means the municipality is still open for almost the double of its current population (MCSDS... 2013), consequently the land of potential development areas in Mārupe is comprised by more than 300 hectares. In the development program of Mārupe regional municipality 2013-2019 (MCSDS... 2013), the suburban landscape is described as 'mosaic style'. In the land use planning document 2014-2026 the main approach is defined as moving towards 'beautiful and put-in-order' environment. The graphical part of the land use planning documents presents areas strictly divided according to their uses, where the widest scope is devoted to private house construction. The housing stock structure and the number of dwellings of Mārupe county is characterized by majority of the residential area being constituted by single-family houses or private houses $(86.4 \%$ out of 2620 units; $55 \%$ out of $857,100 \mathrm{~m}^{2}$ ) (MCSDS... 2013). Despite the fact that one of the major discussion topics in the strategic planning is the employment-induced mobility to Riga (MCSDS... 2013), due to the two-way direction and satisfactory inner employment data, Mārupe cannot be classified as a bedroom district.

\section{Five dimensions of the formation of visual representation of the patchwork- landscape}

Contrary to stereotypes of contemporary suburban life in the Third world ${ }^{3}$, invoking the idea of detachment and instrumental relationship with place (Savage et al. 2010), the satellite communities around Riga present a different view. It does not conform to the concept that suburban life is parcelled ${ }^{4}$ into a soulless and detached housing desert, derived from conventional efforts of the middle-class migrants. On the contrary, it resembles more the description of the 'American dream'. Though, here the tension between space (as a fixed location) and place (as meaningful territory) obviously exists. While the detailed studies of the aforementioned tension moment trace back to the ancient Greeks, recent accounts are indebted to Henri Lefebvre's (1991) analysis (Savage et al. 2010). For Lefebvre capitalism generates an abstract space, as commoditization entails

\footnotetext{
3 Developing countries of Africa, Asia, Latin America and Oceania.

4 Here - massive division of land into parcels.
}

the allotment of land and the use of abstract measures to define space, thus leading to elimination of qualitative judgments of space in favour of quantitative measures. Yet this elimination allows people to redefine and colonize spaces in myriad ways. These myriads are 'patchworks of patchworks', further extended as a historical development, environmental, border, spatial organization and single object description within the case study.

\section{The site and historical development of the 'suburban place'}

In a way directly or indirectly all contemporary landscapes are cultural landscapes, created by people, where the elements and structures bear historical witness. Not fundamental, but essentially contextual is the fact that as Latvia regained its independence (1990), its general political and economic regime in terms of disparity changed from black to white. The state was undergoing a dramatic social-political transformation towards fundamentals of the free market relationship, which concerned majority of processes, including the landscape formation of private households. These changes were implemented without embedded traditions, knowledge and experience, in other words standards, in the European sense.

In 1990 the village of Mārupe was reorganized into a municipality by the territorial expansion and state reforms. Almost 20 years later (2009) the municipality was reorganized into the county, which includes the following 4 villages - Mārupe, Jaunmārupe, Skulte and Tīraine. Historically Latvian planning system has evolved as an attempt to take over the experience of the Western Europe and USA. In the early 1990ies, when the old Soviet planning system was not eliminated yet, the new one had been established. Now, looking retrospectively, the planners conclude that the biggest drawback was that planning (and regulations) has been disconnected from the land privatization process.

Principles and guidelines of land use on the planning level are mainly governed by the legal framework of the territorial planning. It consists of: 1) three laws (Law on Development System Planning (2008); Regional Development Law (2002) and Law on Territorial Development Planning (2011); 2) three Cabinet Regulations (No. 236 (2005); No. 711 (2012); No. 970 (2009); and 3) applicable municipal regulations. The development of the land use plan, public consultation, adoption and entry into force of the procedures of the local authorities have been governed by the applicable municipal regulations, including the municipal territory plans, local layouts and detailed plans (up to 2012). Spatial plan- 
ning tasks are not simple: to assess the opportunities and requirements of municipal area development and the limits for their use; create favourable conditions for business development and investment attraction; make preconditions for quality of the environment and rational use of the area; prevent industrial and environmental risks; guarantee the right to use and develop the real estate in accordance with the spatial plan; promote access to and optimal functioning of the transport system, conserve natural and cultural heritage, landscape and biodiversity, as well as increase the quality of the locality. Their implementation depends on a number of objective problems of the municipality, ranging from money, availability of planning professionals and finally - the lack of experience in spatial planning and land use plan development in general. Since the function of the local government is not only to improve the planning of the local area, but also to ensure its implementation, the local governments often are not aware of the extent of the financial resources they need to develop a plan for implementation.

The zoning status can be changed through the procedure of 'detailed plan transformations' and it has been widely employed - 231 cases in Mārupe since 01.2002 (Data of Marupes... 2013) have been registered. According to this procedure, the parts, which are owned as agricultural or forest land, can be legally modified to any other functional capacity, if they 'are relevant to the laws, regulations and consistent with district plans' (MCTP... 2013; MCDP... 2013). Since law amendments of 07.06 .2012 the estate developments have to be provided by local ${ }^{5}$, detailed ${ }^{6}$ and theme ${ }^{7}$ layouts. The purpose of the updated Spatial Development Planning $\mathrm{Law}^{8}$ is, 'to ensure such spatial development planning that would raise the quality of the living environment, ensure sustainable, effective and rational use of territories and other resources, as well as targeted and balanced development of economy'. ${ }^{9}$ It defines as binding

\footnotetext{
5 Local plan - a long-term spatial development planning document, developed by a local government for a part of the administrative territory thereof (for example, for a part of a town, village or rural territory) in order to solve a planning task or to detail or amend a spatial plan.

6 Detailed plan - detailed plan of a part of local government territory developed in order to specify the requirements for the use of specific land units and building parameters, as well as to adjust the borders of land units and restrictions.

7 Theme plan - a spatial development planning document solving specific issues related to the development of separate sectors (for example, transport infrastructure, layout of healthcare institutions and educational establishments) or specific themes (for example, layout of engineering networks, valuable landscape areas and risk territories) according to the planning level.

8 http://likumi.lv/doc.php?id=63109

9 www.vvc.gov.lv/export/sites/default/docs/LRTA/Likumi/Spatial_ Development_Planning_Law.doc
}

principles of sustainability, succession, equal opportunities, continuity, transparency and integrated approach economic, cultural, social and environmental. Every local government, including that of Mārupe, has to legitimize planning documents according to those principles and in consistency with each other: 1) the sustainable development strategy of the local government; 2 ) the development program of the local government; 3 ) the spatial (territorial) planning of the local government; 4) local, detailed and thematic layouts. Another significant effect on visual outlook of the landscape is made by the documentation 'Terms of Municipal Land Use Planning' - the spatial planning description of the local government, which sets out the requirements for the land use and construction, including functional zoning, public infrastructure, land use and building regulations, as well as other land use requirements and develops the administrative area or a part thereof.

Despite the fact that the aforementioned laws, related to the EU directives, regulations and decisions, have been adopted and are in force, a historically significantly larger impact on the development of private building area in Riga region is established in the economic relations. Using geographers' term 'urban neoliberalism', this phenomenon can be read as a particular intersection of global - in the sense of both general and world-wide - shifts in the structure of capitalist economies and states with the everyday life of people in cities. This is an extension of Henri Lefebvre's notion of the 'urban' as the level of mediation between the global (general) and the personal (lived space). As a state strategy, the urban neoliberalism creates new conditions for the accumulation of capital, yet it also inevitably creates more fissures in which urban resistance and social development can take root (Keil 2002).

Latvia has come a long way with contradictory findings on the issue of national economic policy, until the optimum role and place in a modern society of the market economy was achieved according to the European (EU) understanding (Dovladbekova et al. 2008). During the period, while the optimum implementation of this EU framework was achieved, the construction industry underwent a significant change - it migrated from the strict state supervision to other system, where the core was found in the interpersonal relationships and beneficial business models. During this period the Latvian state economic policies can be divided into three stages (Dovladbekova et al. 2011):

- 1991-1995: the period during which Latvia in a short time had to create the entire economic infrastructure necessary for the normal functioning and re-establishing of material resources. The state 
had to create goods, money, capital, credit, land, and means of production, qualified labour or other economic resources on the market virtually from scratch;

- 1995 - 01.05.2004: the period, during which Latvia had made the request to join the European Union, and did everything necessary to adapt its legislation and macroeconomic indicators to the EU requirements;

- 01.05.2004-01.01.2014: the period, during which, the main objective was to achieve the fulfilment of the Maastricht criteria (Latvia was admitted to the European Monetary Union (EMU)).

The first two of the three stages in the country's economic policy have been strongly focused on paving the path for a fundamental condition of neoliberalism - minimizing the role of the state in today's business economy (Dovladbekova et al. 2008). This philosophy is closely connected to the politics of classic liberalism, where significant part of 'everything' becomes a 'product of trade', including architecture and built-up environment sections. Here the general idea was to liberate the market from any regulations, thus enabling the corporations to conform 'process', which as liberals think should run completely free and without restrictions, leaving it to the rules of nature and economics (Peck, Tickell 2002). It had theoretical, ideological and pragmatically focused grounds, becoming a true 'market fundamentalism' and a 'free market orthodoxy' (P. R. Krugman) in the transition economy of Latvia. Market approach and culture in Western Europe has been approbated for nearly two centuries and is based on rational analysis and linear thinking. It is different, if we focus on the case study located in Latvia. Here reference to a quasineoliberalism can be made; in other words, the free market implementation and political transformation happened in a remarkably accelerated speed by the Washington's consensus principle (Dovladbekova et al. 2008).

Most of the analysed suburban landscape has been shaped during the third stage, the period from 2004-2008, which is related to the accession to the EU and the availability of financial resources and following rapid credit expansion. It reflects the living conditions of a particular time period, revealing the history of the site. In the architectural and spatial display, the formation in built-up environment during the last 23 years was developing based on a strong belief in the power of business, ideological attack upon the notions of collectivism and support to the values of architectural individualism (Fig. 5).

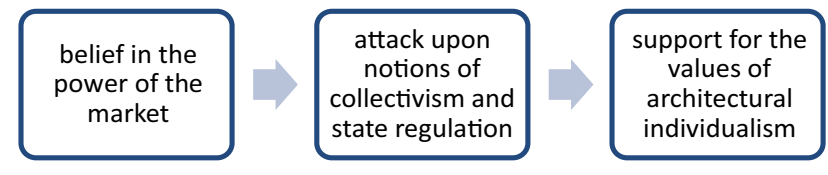

Fig. 5. The credentials in the built-up environment development during the last 23 years (author's visualisation, 11.2013)

\section{The environmental context}

Environmental context here is recognized as a challenge of sustainability under the context of legislation, strategic planning and actual observations. There is a tremendous variation in the definition, but the most likely interpretation of sustainable architecture implies perceiving it as a balance between re-discovering of the bioclimatic principles, local building traditions emerging from the context and ingenious innovations that diminish resource use (Drexler, El Khouli 2012).

The state regulation provides for several laws, relevant to the environmental context - the Construction Law (1995, 2014); Law On Specially Protected Nature Territories (1998); Law on Environmental Impact Assessment (1998); Law on the Conservation of Species and Biotopes (2000); Environmental Protection Law (2006); Protection Zone Law (1997) and the Land Survey Law (2006); Law on Forced Expropriation of Real Estate for the State or Public Needs (became null and void in 2011).

The development strategy documents of the Riga region (for the forthcoming period of 2014-30) comprise several documents with visionary targets for environmental quality (MCDP... 2013; MCSDS... 2013), excluding specific focus areas. According to the development strategy plan of the Mārupe County, its territory does not include valuable micro-reserves and any natural monuments. According to the general description, it is a typical landscape of the RES (residential) landscape, single-family and low-rise residential buildings. This landscape can be categorized as being of local significance, having importance within the area and in regard to nature reserves there is only the moorland of Cena and several big trees (MCSDS... 2013) mentioned.

The strategy plan shows contemporary targets for 'a living space' - accessibility, mobility, qualitative infrastructure and tidy environment (MCSDS... 2013). The geographical location of the county, including the presence of the airport area, creates a 'good preconditions for business development, particularly in the areas related to transport logistics and production sector. Simultaneously, as stated in the development strategy documents, the area has to take into account the 
proportion of agricultural land to be preserved and developed for agricultural production' (MCSDS... 2013). It is difficult to mention the presence of urban - rural practical collaboration, as none of the families use or plan to use their land for food production (Darbina, Luse 2006). A rapidly increasing spread of the private new buildings can be observed, often implemented on agricultural lands or forest sites (MacLeod, Ward 2009). Thus agricultural and forest landscapes become dominated by large areas with an increasing proportion of residential building construction. Harvey interconnected the processes and made the remark that the liberalization of the urban space has created some deeply entrenched geographic disparities in wealth and power, fashioning a metropolitan world of chronically uneven geographical development.

Wealth moves to exurban spaces that explicitly exclude the poor and the marginalized (Punch 2009) or hides behind high walls in suburban privatopias and enclosed ${ }^{10}$ urban communities. For Harvey the effect is dividing up the urban realm into a patch-work quilt of islands of relative affluence, struggling to secure their precarious prosperity in the sea of spreading decay, which leads to a profound division and fragmentation (MacLeod, Ward 2009). Besides, technological solutions in these new settlement clusters are mostly primitive, where lack of infrastructure is often solved individually and still no political standards for sustainable development are set. In the architectural and spatial display, the patchwork image reflects the economic growth and increase of domestic economic activities during a given time, but it does not represent mutual integration of infrastructural solutions and spatial development in general (Kḷaviņš, Zaḷoksnis 2010).

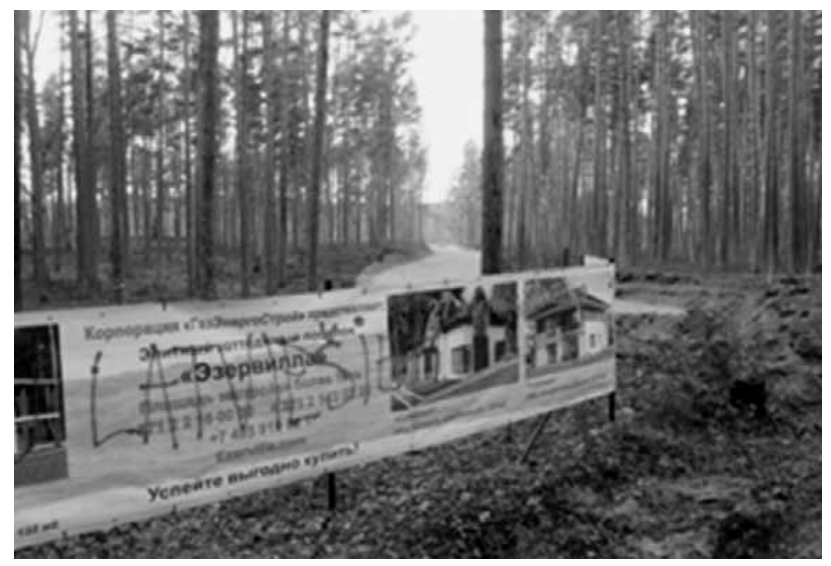

Fig. 6. Expanding 'gentrification' in brown fields and forests. Emerging 27 'elite' private houses settlement 'Ezervilla', located $50 \mathrm{~km}$ from Riga (author's photo fixation, 11.2013)

\footnotetext{
${ }^{10}$ Here as communities, which territorially are enclosed behind physical demarcation, as fences and gates.
}

\section{The borders}

Within environmentally unsustainable and growing spatial structures two closely linked subjects - borders and spatial organization - become applicable and also much interconnected. Borders are established administratively and privately, but they are not visible (unless we consider private fences) for recognition of a separate community's identities or multifunction existence. The development of Mārupe County does not provide any spatially readable differences between villages (Fig. 7).

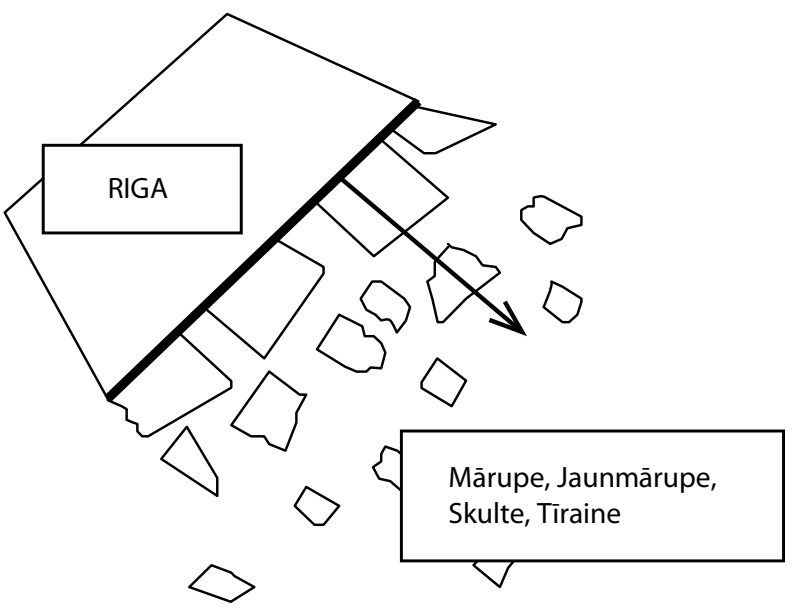

Fig. 7. Diffusion without visible borders (reconstructed on Pužulis 2012)

Back in 2009 local geographers from the University of Latvia made a research on the habitation structure in the Riga region (Pužulis, Šķiņķis 2009), resulting in 8 main conclusions on problems and 9 key suggestions. Problems concerned scattered structure of 'meadow villages', market pressure and speculations, expansion on the expense of forests, inadequate spatial planning, lack of development, historic core basis and any calculation basis other that profit. Suggestions included a need for sub-area population structure model, possible consolidation of scattered established territories, need to analyse the sub-area in regard to its functional unity and obligation to synchronise the waves of development and market changes, as well as a practical need for general vector graphical format of these territories. Authors distributed 2-3 development circles (Fig. 8).

The development circles are characterized by the differences in the development processes:

- Residential landscape of Mārupe, the first circle (Fig. 9; Fig. 8, map designation La 1).

- Residential landscape of Mārupe, the second circle (Fig. 10; Fig. 8, map designation La 2).

- Residential landscape of Jaunmārupe (Fig. 11; Fig. 8, map designation La 3). 
- Residential building landscape of Mārupe - the club - type village (enclosed territory) (Fig. 12; Fig. 8, map designation La 4), representing an example of typical 'enclosed community' in the form of high walls and guarded gates (MacLeod, Ward 2009).

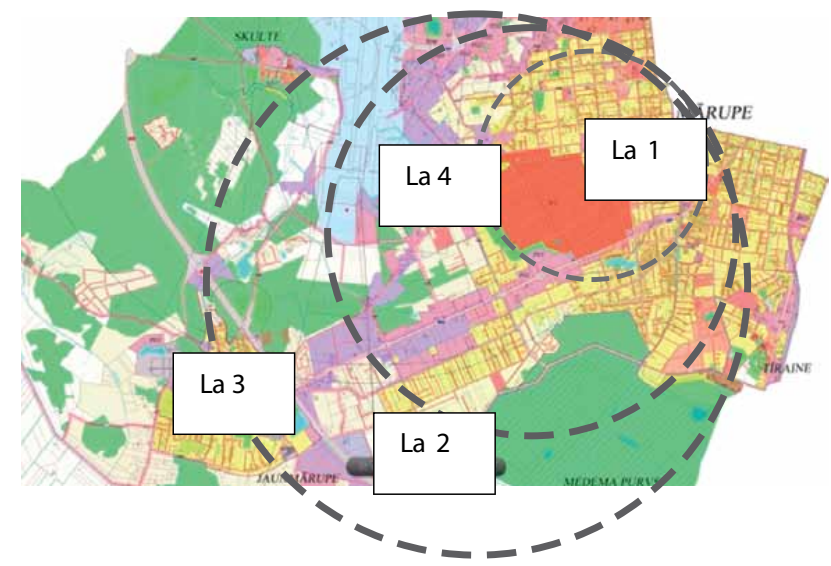

Fig. 8. Scheme of Mārupe municipality with the development circles (author's visualization, 10.2013)

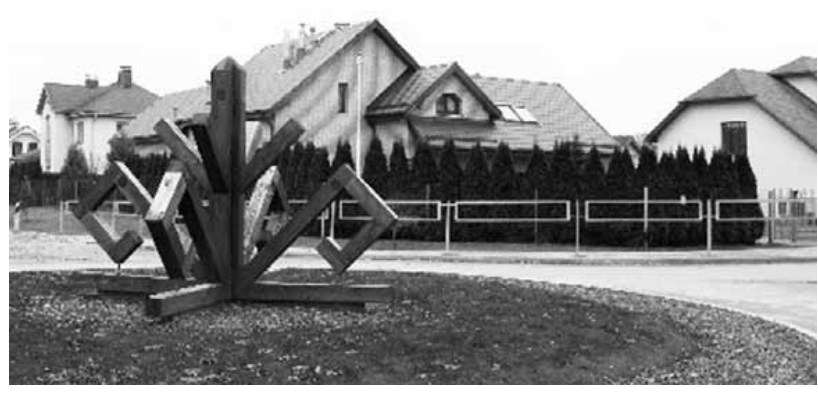

Fig. 9. Type 1, Mārupe, the first circle (historical, 'traditional' suburb), (author's photo fixation, 11.2013)

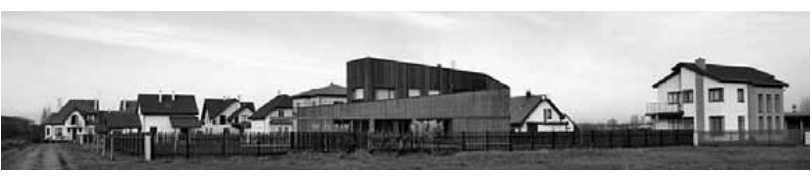

Fig. 10. Type 2, Marupe, the second circle, (author's photo fixation, and 11.2013)

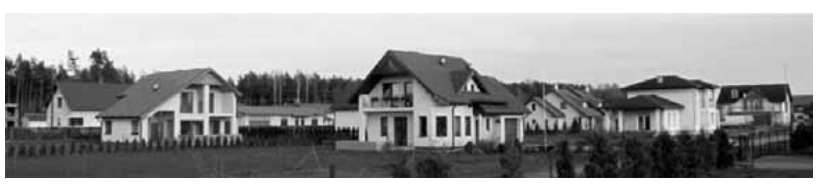

Fig. 11. Type 3, Jaunmārupe, further expansion (author's photo fixation, 11.2013)

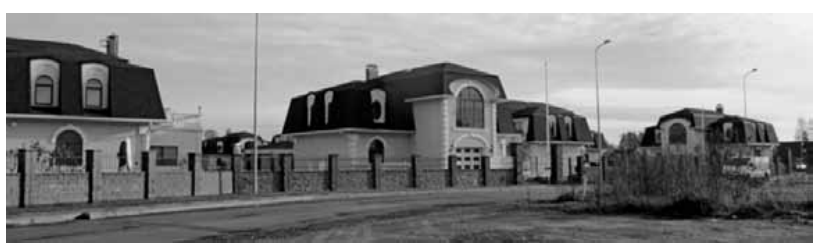

Fig. 12. Type 4, Mārupe, club - type 'Old Captain', (author's photo fixation, 11.2013)
The case study shows that the spatial organization is coded according to the market impact and can rather be classified according to the periods of resource availability and project initiatives of the village developers within 'the development periods', rather than the planning conditions or intentions of the professionals. These processes can be defined and discussed as relevant (and dominant) to spatial formation objectives, where architectural outcome often became a combination of finance availability and coincidence of circumstances. At least three periods of suburban development periods can be established within the periodization and it is obviously 'readable' in the landscape (Figs 9-12).

\section{The spatial organization}

Another corner stone of spatial structure is found in relations between objects and their mutual arrangement. As no other two concepts have made a stronger impact on the nature of humans and society than collectivism and individualism $^{11}$, Hofstede ${ }^{12}$ maintains that in collectivist cultures people are communal, interdependent and influenced by their groups, whereas in individualistic cultures people are self-focused and tend to be based on their own attitudes and not that of the group. In a way this individual-collective struggle, where the neo-liberalism advocates the first, can be observed. The case study shows how twisted this topic has become under the market understanding. Patchwork outfit examines 'dichotomy between the public and the private space and finds it to be more apparent than real insofar as it is difficult to claim a sharp conceptual distinction between the two; moreover, the social benefits of public space are shown to be overdrawn, while those of private space are shown to be commonly overlooked', writes Andrew Kirby, the editor of interdisciplinary Elsevier journal 'Cities' (Kirby 2008).

Public life and territorial planning are primarily concerned with the balancing of public and private relations, where community interests and values are implemented through different practices. Individual practices may be private-centric or dualistic, balancing personal and public interests and thereby strengthening both. This is reflected in the conditions of political transformations, especially in the planning of territorial development (Darbina, Luse 2006). In the case study most of dwelling expansions are mono-functional, representing only the living dimension. The obvious collective planning efforts can be observed

\footnotetext{
${ }^{11}$ Collectivism/Individualism: SAGE Knowledge, http://knowledge. sagepub.com/view/identity/n38.xml (accessed March 3, 2014).

${ }^{12}$ Dutch social psychologist.
} 
only in 'club-type' enclosed communities, implemented to increase the sales price. The local planning policies do not insist on a necessity of public spaces, social infrastructure or cultural expressions, because private property cannot be challenged. It is a paradox that the issue of privacy is the main conflict source in the subject of housing, which has to include the integration of individual buildings in the urban context.

The case study supports the fact that borders and spatial organization are manipulated by market conditions rather than local planning regulations or urban design guidelines for quality dwelling standards. Spectacular advertisements in the press are promising quiet, peaceful life in the forest, birdsongs and sunrise. The average customer lacks knowledge about the necessity of guaranteed village infrastructure, lighted streets, and sidewalks and does not consider that besides a residential building design the urban development standard provides stores, nursery, leisure complexes and public plaza opportunities.

\section{The object}

Landscape is a puzzle, in which each piece of the suburban landscape - a single household unit - presents something diverse (Fig. 1; 13; 25). The majority of these suburban expansions has never been considered in professional discussions as 'architecture in urban design' and often are referred to as 'background built-up environment' or conventional construction. However, as such, it also reflects the true features of the region. Since visual representation in the suburban architectural display is tightly linked to its identity and diversity, it is necessary to clarify the meaning of diversity and its representation at local level. According to SAGE, the urban encyclopaedia ${ }^{13}$, diversity refers to all facets of variability found in nature and throughout society. Some features of human diversity are genetically predetermined, some are socially constructed, and still others derive from both biology and culture (Makau 2010).

Local building regulations define such physical characteristics of buildings as their height, number of floors, total scale and density, and uniform compliance thereof is a fact. Regulations do not specify any visual parameters and aesthetic guidelines. The local implementation documents of the Landscape Convention point out to the 'problem' of private property priorities, human rights and freedom to choose as being the main obstacle for gaining spatial quality. The EU Landscape Convention does not object to

\footnotetext{
${ }^{13}$ Diversity : SAGE Knowledge, http://knowledge.sagepub.com/view/ identity/n76.xml (accessed March 3, 2014).
}

differing visual aesthetics, which predominantly defines the regional identity: 'reflection of European identity and diversity, where the landscape is our living natural and cultural heritage, be it ordinary or outstanding, urban or rural, on land or in water' (European Council... 2000). Finally the policy of the Royal Institute of British Architects (RIBA) claims that stylistic preference cannot be used as a criterion for assessment (Kellow 2006). The case study shows that here the diversity can be observed in at least three socio-economical categories.

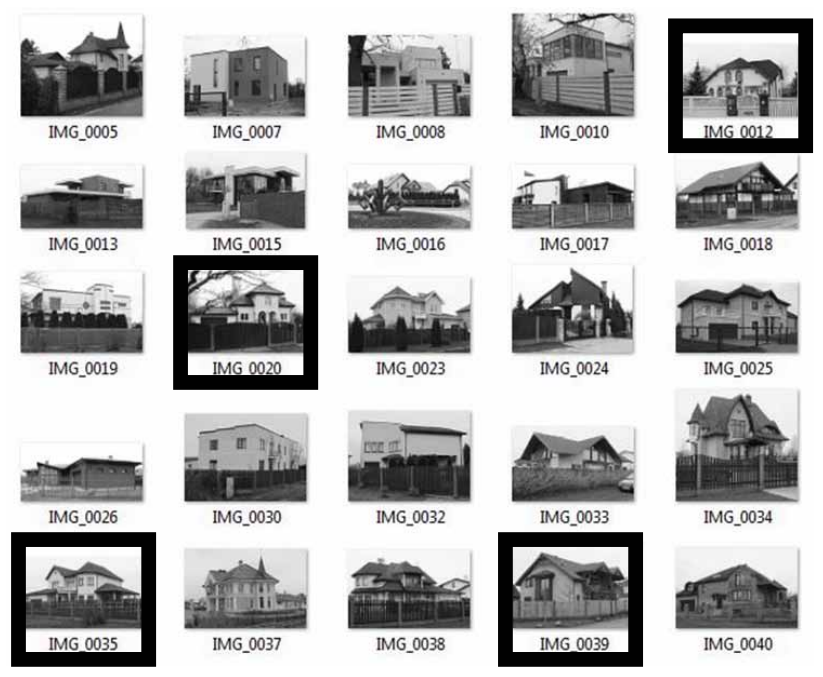

Fig. 13. Display of diversity and disparity, the 'object formation visuals" ${ }^{14}$ (author's photo and visualization, 11.2013)

First diversity section addresses the urban anthropology related to culture and social change. The sources of identity most often associated with anthropological diversity include the race of the individual or the group, ethnicity, religion, sexuality, gender, age, socioeconomic status, geographic conditions, job or profession, physical capacities and limitations, age, communal memberships, character traits, interests, values and beliefs (Makau 2010). In the visual audit of the landscape, only one disparity can be recognized instantly the socio-economic status (in the form of income level).

Second variety section can be referred to as the architectural stylistic preference. Private houses and estates - which constitute the majority of the described landscape - always include some notion of isolation and individualism, but in this case remarkable fragmentation in stylistic preference can be identified. Since everybody has officially accepted rights to choose the most fitting aesthetics, visual audit endorse reflections and hybridizations from nearly all typologies produced by the European civilizations.

\footnotetext{
${ }^{14}$ Here, 'formation' means 'the process' (not 'the shape').
} 


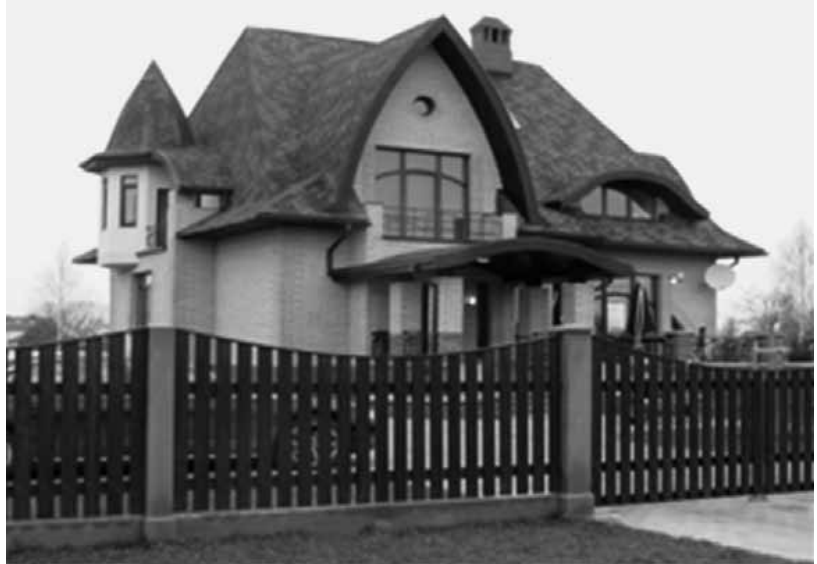

Fig. 14. The object formation visual, visual example No. 1, (author's photo, 11.2013)

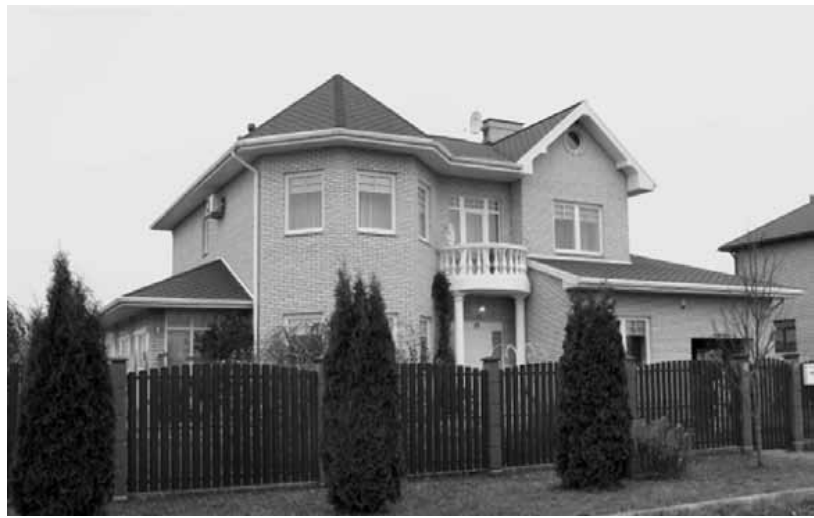

Fig. 15. The object formation visual, visual example No. 2, (author's photo, 11.2013)

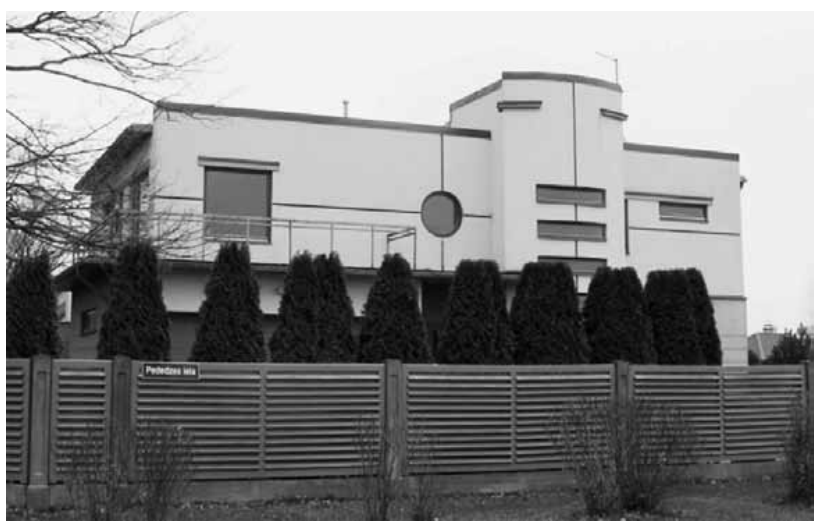

Fig. 16. The object formation visual, visual example No. 3, (author's photo, 11.2013)

Images and elements of different styles in architecture, such as classicism, historicism or modernism (Figs 13, $15,19,21,23)$, can be observed, as well as synthesized regionalism (Figs 16, 18, 24). Distinctive are images of 'subsidiary styles' such as wide interpretation and intensity range of neo-isms, eclecticism or brutalism (Figs 16, 17). There is also a wide-spread 'conventional style' (Fig. 22) and traces of local vernacular (Fig. 20) formations.

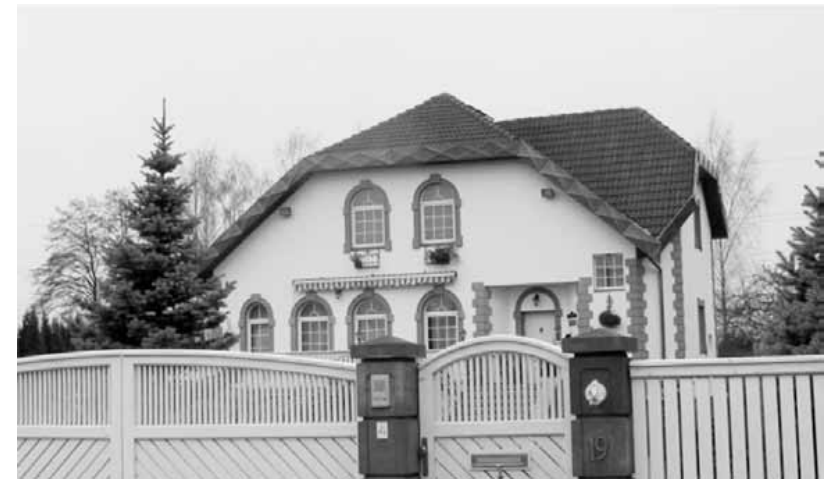

Fig. 17. The object formation visual, example No. 4, (author's photo, 11.2013)

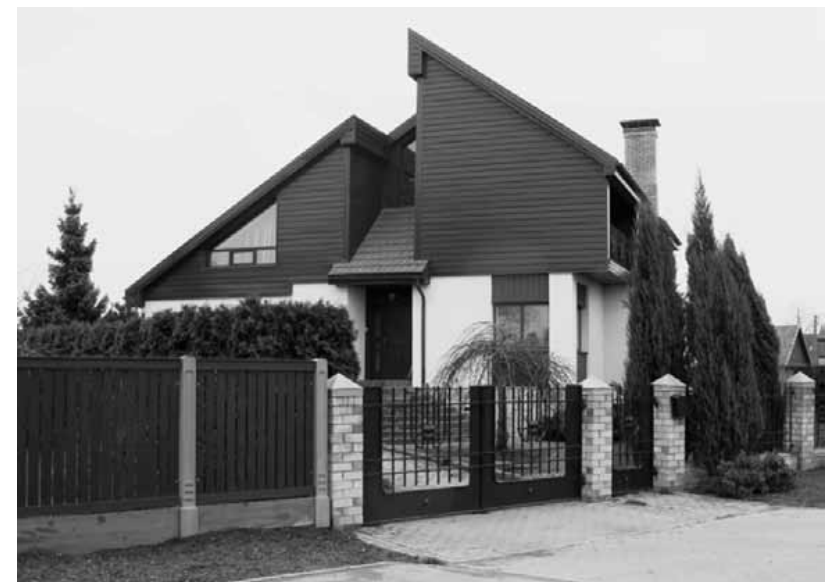

Fig. 18. The object formation visual, example No. 5, (author's photo, 11.2013)

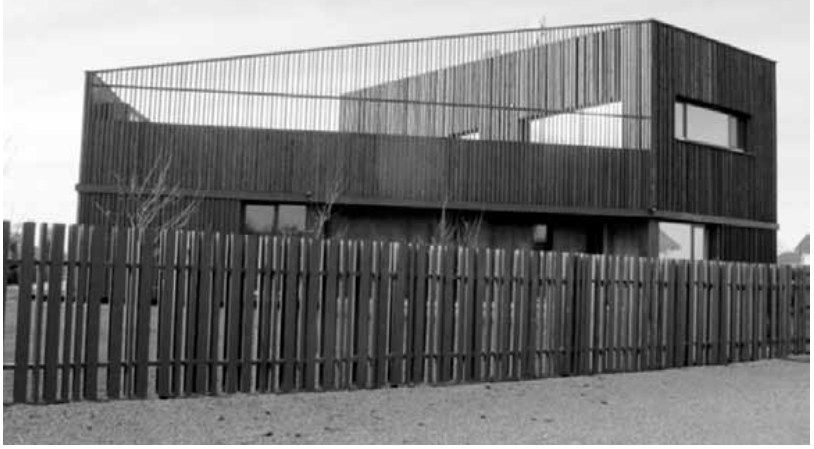

Fig. 19. The object formation visual, example No. 6 , (author's photo, 11.2013)

The third assortment section concerns disparity addressing the construction quality performance (Figs 21, 22 and Figs 14, 15). Notable inequality in the socioeconomic status differences of the owners, which are defined by income, credit obligations and welfare awareness, can be observed. These are supported by disagreements within the total market sector of the built-up environment as a 


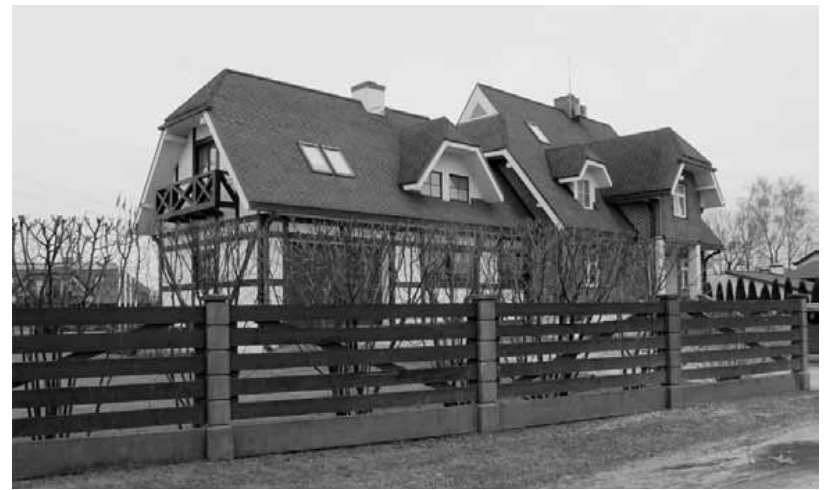

Fig. 20. The object formation visual, example No. 7 , (author's photo, 11.2013)

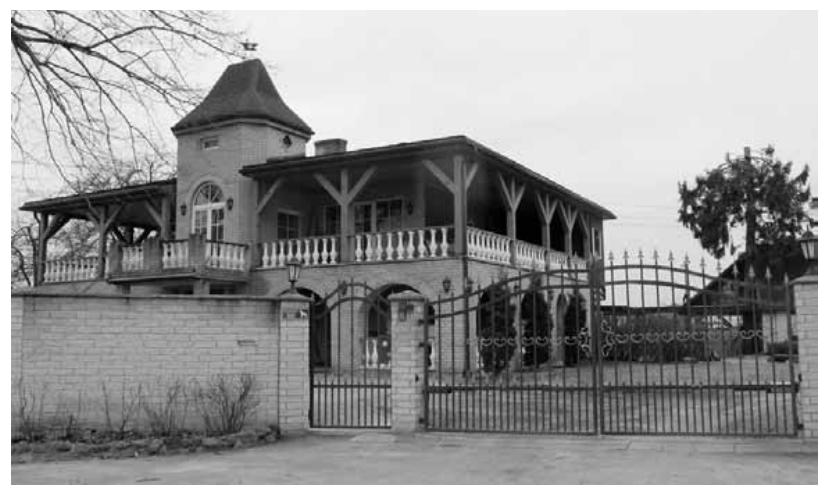

Fig. 21. The object formation visual, example No. 8, (author's photo, 11.2013)

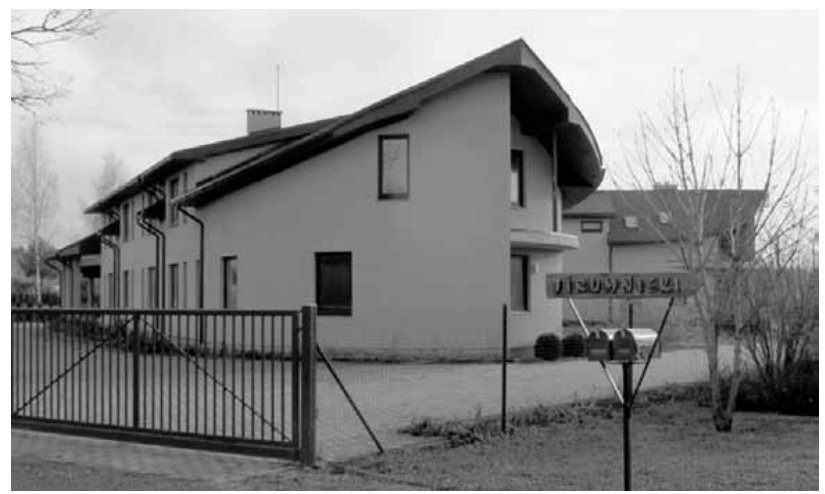

Fig. 22. The object formation visual, example No. 9 , (author's photo, 11.2013)

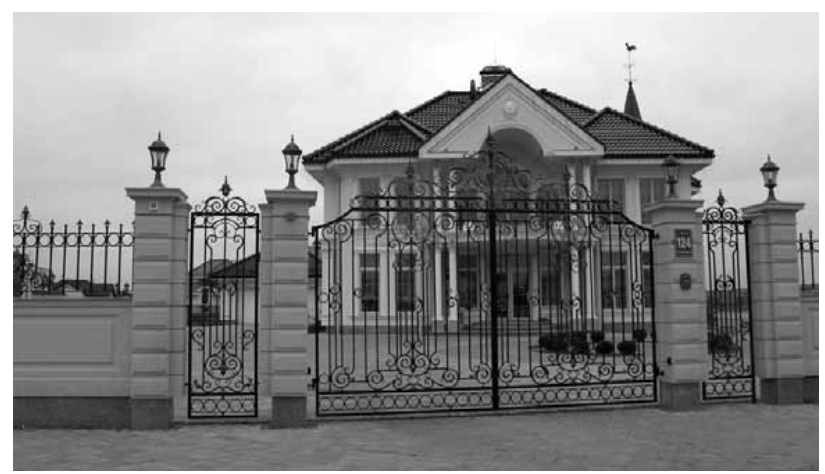

Fig. 23. The object formation visual example No. 10, (author's photo, 11.2013)

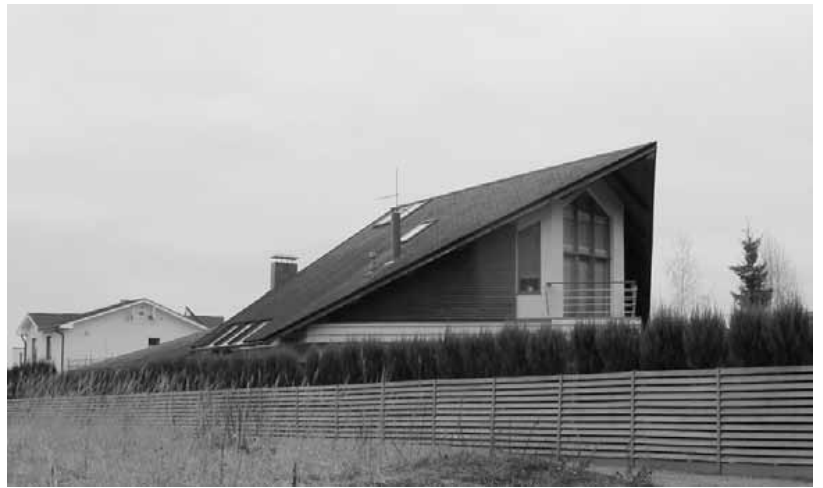

Fig. 24. The object formation visual example No. 11, (author's photo, 11.2013)

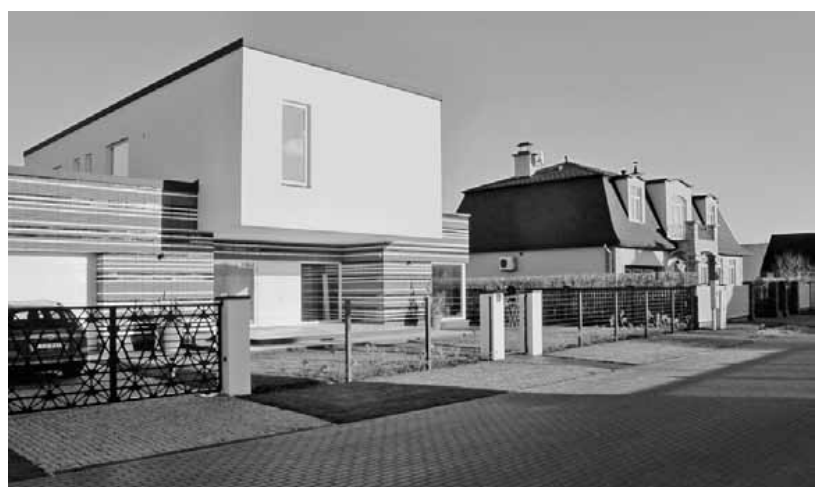

Fig. 25. The aesthetic diversity coexistence in the object formation, (author's photo, 11.2013)

growing gap between the "good", highly-financed, professional architecture with quality assurance and the increasing volume of "poor", low-financed, conventional construction.

Researchers of Riga Stradina University (RSU) on the subject of suburban development (2012) have made a notable questionnaire points that here one can find a mixture, where variety of people live - the poor, the well-off 'natives' and the owners of the new private houses, many of them have an unclear future vision of their house (Darbina, Luse 2006).

These disparities mostly have been attributed to the economic restructuring, neoliberal policies, heightened influence of aggressive entrepreneurial interests on public policy and the role of finance and speculative business interests.

\section{Conclusions}

Significant panoramic and systemic consequences, known as the "regional agglomeration landscape", have been observed during the last 23 years. This landscape, characterized by residential building units close to the economic centers, consists of fragments formed by privately owned objects, which reflect the summary of the local planning and market economy policy trends. 
The state policies regarding territorial planning and regulation show an exceptional descriptive part at the urban planning level, compliant with high European standards, but essentially lack the development of relevant documentation to achieve a good quality urban design (spatial setting). Landscape in Latvia, being a subject recognized as a significant regional characteristic and regulated by the law, is a relative novelty. Its descriptions are mostly general. Whereas the market self-determination mode and individualism are dominating, it is hard to achieve the quality of the landscape beyond the written postulates. It still lacks the development of contemporary classification, and professional construction of the landscape lacks experience and guidelines.

The analysis of the case study shows that asymmetrical relationship between the pronounced spontaneous growth and lagging state and municipal planning regulations have caused certain imbalance between the urban spatial values, including such foundation stones of modern quality as sustainable attitude towards environment and resources, available multi-functionality, spatial, aesthetic and physical quality of the buildings. It leads to analytical conclusions in five dimensions, which have had the most significant impact on the landscape as we witness it today.

Historical context, in the research object as a geographical area, reflects the transition from collectivism to individualism, which dominated during the last two decades under the accelerated mode of development in the social, economic and political spheres.

Environmental context, as taken apart of nature reserves, can be stated in at least two prior-liberally focused categories. First is continuous digest of brown fields and forests, instead of increasing density in the existing urbanized areas. The second concerns lack of environmental sustainability in technological and utilitarian solutions, proofing the fact that growth does not necessarily indicate development.

Border context, as lack of visual spatial distinction between different communities, except the timeline recognition in availability of financial resources.

The spatial organization, as self-determination of urban fabric, includes serious errors of urban design quality standards, for example, lack of public space, diverse functionality or landmarks.

The objects, as evidence of 'individuality expansion', both in stylistic diversity and quality disparity, create explicit regional identity.

Despite the fact that 'suburbanization product' is still expanding and is one of the most notable processes of urban spatial restructuring in Latvia since the end of the communist regime, the dimensions of its development are weakly covered by standards, guidelines and local planning performances. The processes influencing and at the same time reflecting the local suburban reality in the mirror of the landscape are mostly dictated by the private individualism and neoliberal philosophy. The role of the state intervention turned out to be insufficient towards socioeconomics of the private sector. As such the suburban residential architecture and spatial display are defined by the neoliberal opportunities and relationships rather than urban planning and urban design standards.

\section{References}

Beauregard, R. A. 2010 Encyclopedia of urban studies. University of Wisconsin, Green Bay, Urban Agglomeration, 839-884. ISBN: 9781412971973.

Brenner, N.; Theodore, N. 2002. Preface: from the "New Localism" to the Spaces of Neoliberalism, Antipode 34: $341-347$.

Canizaro, V. 2007. Architectural Regionalism: collected writings on place identity modernity and tradition. New York, Princeton: Architectural Press. 14 p. ISBN-10:1568986165.

Darbina, G.; Luse, A. 2006. Development of suburbs in the context of post-socialist consumption models: the case of Pierīga, European Integration Studies 6: 101-110, 109, 97. ISSN $1822-8402$.

Data of Marupes, Mārupes Būvvaldes dati [Marupes county construction board] [online], [cited 20 November 2013]. 2013. Available from Internet: http://www.marupe.lv/wp-content/ uploads/2013/07/Detalplanojumi-Nr.pdf (in Latvian)

Dovladbekova, I.; Eteris, E.; Zelmenis, D. 2008. Eiropas Savienības ekonomiskā politika un Latvija [The European Union's economic policy and Latvia]. Rīga: Riga Stradina University. 349 p. (in Latvian).

Dovladbekova, I.; Zelmenis, D.; Eteris, E. 2011. Mūsdienu finanšu un ekonomiskā krīze Eiropā un Latvijā: izeju meklējot [Today's financial and economic crisis in Europe and Latvian: searching for a way out]. Riga: Riga Stradina university, 110, 104 (in Latvian).

Drexler, H.; El Khouli, S. 2012. Munich: Institut fur Architektur Dokumentation GmbH\&Co.KG Holistic Housing. Bobingen: Kessler Druck+Medien. ISBN: 987-3-920034-78-2. 10 p.

ELC 2000. Likums 'Par Eiropas ainavu konvenciju' [The European Landscape Convention] European Council Florence, 20.10.2000 [online], [cited 20 December 2013]. Available from Internet: http://www.coe.int/t/dg4/cultureheritage/ heritage/Landscape

Keil, R. 2002. "Common-sense" neoliberalism: progressive conservative urbanism in Toronto, Canada, Antipode 34: 578-601.

Kellow, P. 2006. Architecture and ideology [online], [cited 10 October 2013]. INTBAU, France. Available from Internet: http://www.intbau.org/archive/essay $15 . h t m$

Kirby, A. 2008. The production of private space and its implications for urban social relations, Political Geography 27(1): 74-95. ISSN 0962-6298. 
Kḷaviņš, M.; Zaļoksnis J. 2010. Vide un Ilgtspējīga attīstība [Environment and sustainable development]. Riga: Latvia University. ISBN 978-9984-45-220-3. 160 p. (in Latvian).

LPG 2007 Ainavu politikas pamatnostādnes 2013-2019gadam [Landscape policy guidelines 2013-2019] [online], [cited 12 November 2013]. Available from Internet: http://www. VARAMpamn_21062013_ain (in Latvian).

Lefebvre, H. 1991. The production of space. Cambridge, MA: Blackwell. ISBN 0-631-18177-6. 26 p.

Mace, A. 2009. Suburbanization, in Kitchin, R.; Thrift, N. (Eds.). International encyclopedia of human geography. Oxford: Elsevier, 77-81. ISBN 9780080449104.

MacLeod, G.; Ward, K. 2009. Encyclopedia of urban studies: patchwork urbanism. SAGE Knowledge, 3-8. ISBN: 9781412971973.

Makau, J. M. 2010. Encyclopedia of identity: diversity. SAGE knowledge, 236-237. ISBN: 9781412979306.

MCDP (Marupes County Development plan 2013-2019.) [Mārupes novada attīstības programma 2013-2019] [online], [cited 20 December 2013]. 2013. Available from Internet: http://www.marupe.lv/Marupes-novada-attistibas programma-2013_2019-gadam.pdf (in Latvian).

MCSDS Mārupes novada ilgtspējīgas attīstības stratēgija 2013-2026 [Marupes county sustainable development strategy 2013-2016] [online], [cited 20 December 2013]. 2013. Available from Internet: http://www.marupe.lv/wp-content/ uploads/2013/05/Marupes-novada-ilgtspejigas-attistibasstrategija-2013_2026-gadam.pdf (in Latvian).

MCTP Mārupes novada teritorijas plānojums 2014-2026 gadam [Marupes county territory plan 2014-2026] [online], [cited 20 December 2013]. Available from Internet: http://www. marupe.lv/speka-stajies-marupes-novada-teritorijas-planojums-2014-2016-gadam (in Latvian).

McGuirk, P.; Dowling, R. 2009. Neoliberal privatisation? Remapping the public and the private in Sydney's masterplanned residential estates, Political Geography 28(3): 174-185. ISSN 0962-6298.

Nikodemus, O.; Bell, S.; Grīne, I.; Liepiňš, I. 2005. The impact of economic, social and political factors on the landscape structure of the Vidzeme Uplands in Latvia, Landscape and Urban Planning 70(1-2): 57-67. ISSN 0169-2046.

Nira research, 2004. Pètījums par nekustamā īpašuma tirgus attīstības procesiem un to ietekmi uz Rìgas teritoriālo attīstību [A study of real estate market development processes and their impact on the development of the territory of Riga] [online], [cited 18 November 2013]. Available from Internet: http://www.rdpad.lv (in Latvian).

Peck, J.; Tickell, A. 2002. Neoliberalizing Space, Antipode 34: 380-404.

Punch, M. 2009. Encyclopedia of Urban Studies: Uneven Development. SAGE knowledge, 834-837. ISBN: 9781412971973.

Pužulis, A. 2012. Robežu loma geogrāfiskajā telpas organizācijā Latvijā [Border role of geographical space organization Latvian]: Dissertation. Faculty of Geography and Earth Sciences, Latvia University, Riga. 77 p. (in Latvian).

Pužulis, A.; Šḳiṇkis P. 2009. Pierīgas apdzīvojuma struktūras izpēte [Study of population structure in Subriga] [online], [cited 12 December 2013]. 20 p. Available from Internet: http://www.rpr.gov.lv/uploads/filedir/Uzraudziba/ Pierigas\%20apdzivojuma\%20struktura.pdf (in Latvian).
RSDS 2030 Rìgas ilgtspējīgas attīstības stratēgija lìdz 2030. gadam [Riga Sustainable Development Strategy 2030]. 2013 (in Latvian).

RCL Rìgas pilsētas ainavu teritoriju izdalī̌sana, analīze un novêrtēšana [Riga City Landscape areas isolation, analysis and evaluation] [online], [cited 12 December 2013] 2009. Latvia University, Faculty of Geography and earth Sciences. Available from Internet: http://www.sus.lv/files/ainava atskaite_kopaa.pdf (in Latvian).

Savage, M.; Bagnall, G.; Longhurst, B. 2010. Suburbia and the Aura of Place, Globalization and Belonging, Chapter 4: Suburbia and the Aura of Place. $78 \mathrm{p}$.

Soja, E. W. 2009. Regional planning and development theories, in Kitchin, R.; Thrift, N. (Eds.). International Encyclopedia of Human Geography. Oxford: Elsevier, 259-270. ISBN 9780080449104.

Van Eyck, A. 1962. The child, the city and the artist; an essay on architecture; the in-between realm. Ligtelijn V.; Strauven, Fr. (Eds.). Amsterdam: SUN publishers. 236 p.

Zigmunde, D. 2010. Harmonization of landscape aesthetics and ecology in the context of sustainable planning, scientific [Estētiskās un ekologiiskās saskaņas sintēze unilgtspējīgas ainavas plānošanas kontekstā], Ilgtspējīga Telpiskā Attīstība 1: 94-98. Riga: RTU scientific writings.

\section{PAGAL UŽSAKYMĄ PAGAMINTA MOZAIKA: VERSLO IR PRIVATUS REGIONALIZMAS}

\section{Miķelsone}

\section{Santrauka}

Regioninis identitetas kaip naujai išrastos tradicijos samprata yra nuolatos atnaujinama visoje Europoje; šis procesas yra ypač dèsningas tokių nedidelių šalių, kaip Latvija, kultūrose. Tai daugiasluoksnis reiškinys, apimantis besikeičiančias, ị vertybes orientuotas disciplinas, taip pat ir architektūrą. Vienas iš būdu ị tai žiūrèti realistiškai - analizuoti vizualiai reprezentuotas pagrindines hegemonines vertybes ir procesus visuomeneje. Tam tikrą platformą šiam reiškiniui teikia aglomeracijos plètra miestietiškumo ir kaimiškumo sintezè, kurianti charakteringą vietinị kraštovaizdị. Šio straipsnio tikslas - išsiaiškinti nūdienos Rygos regiono kraštovaizdžio esmini poveikị regioninio identiteto formavimui. Metodologija yra pagrịsta Mārupe apygardos tyrimu, kuriam naudotas RES (gyvenamojo) kraštovaizdžio aprašo, miestų morfologijos, fotoanalitinis ir retorinis problemos ivardijimo metodai. Tyrimo rezultatai veda prie išvados, kad valstybės įsikišimo vaidmuo ir laisvoji prekybos sistema, pagrịsta neoliberalia ideologija, nèra subalansuoti ir tai sustiprejja pereinamosios ekonomikos zonoje. Taigi regioninis erdvinis identitetas ne tikslingai grindžiamas profesionaliais standartais, o vystosi daugiau kaip gyvenamosios paskirties zonos, stipriai veikiamos rinkos ekonomikos ir verslo.

Reikšminiai žodžiai: regioninis erdvinis identitetas, priemiesčių kraštovaizdis, neoliberalai, pereinamoji ekonomika, kraštovaizdžio mozaika. 